\title{
The adaptation of MAIN to Turkish
}

\author{
İlknur Maviş
}

Anadolu University

\author{
A. Müge Tunçer \\ Anadolu University
}

\section{Semra Selvi Balo}

Anadolu University

This paper presents a short overview of Turkey and the Turkish language, and then outlines the process of adapting the Multilingual Assessment Instrument for Narratives (MAIN) to Turkish and how the Turkish MAIN has been used with monolingual and bilingual children. The grammatical features of Turkish, the critical points in the adaptation process of MAIN to Turkish and our experiences of extensive piloting of the Turkish MAIN with typically developing monolingual children are described.

\section{Introduction}

Turkey occupies a unique geographic position, lying as a bridge, partly in Asia and partly in Europe (see Figure 1) so Turkey is culturally influenced by both Europe and Middle East. The current population of Turkey is 84,068,992 as of 2020 (Worldometer, 2020). According to the previous studies, more than 3 million people of Turkish origin live abroad. Over a million speakers of Turkish are found in Bulgaria, Macedonia, and Greece, over 1.5 million live in Germany and other northern European countries, including Belgium, France, Denmark, and England (Schaufeli, 1991; Yağmur, 1997), and about 24,000 Turkish speakers live in the United States (Grimes, 1992; Turkish Ministry of Affairs, 2003; cited in Topbaş, 2006). Eighty four percent of the population in Turkey speaks Turkish as the official language, however, Kurmanji and/or Zazaki dialects and Arabic can be listed as minority and immigrant languages in Turkey, some of which are spoken by large numbers of people. 


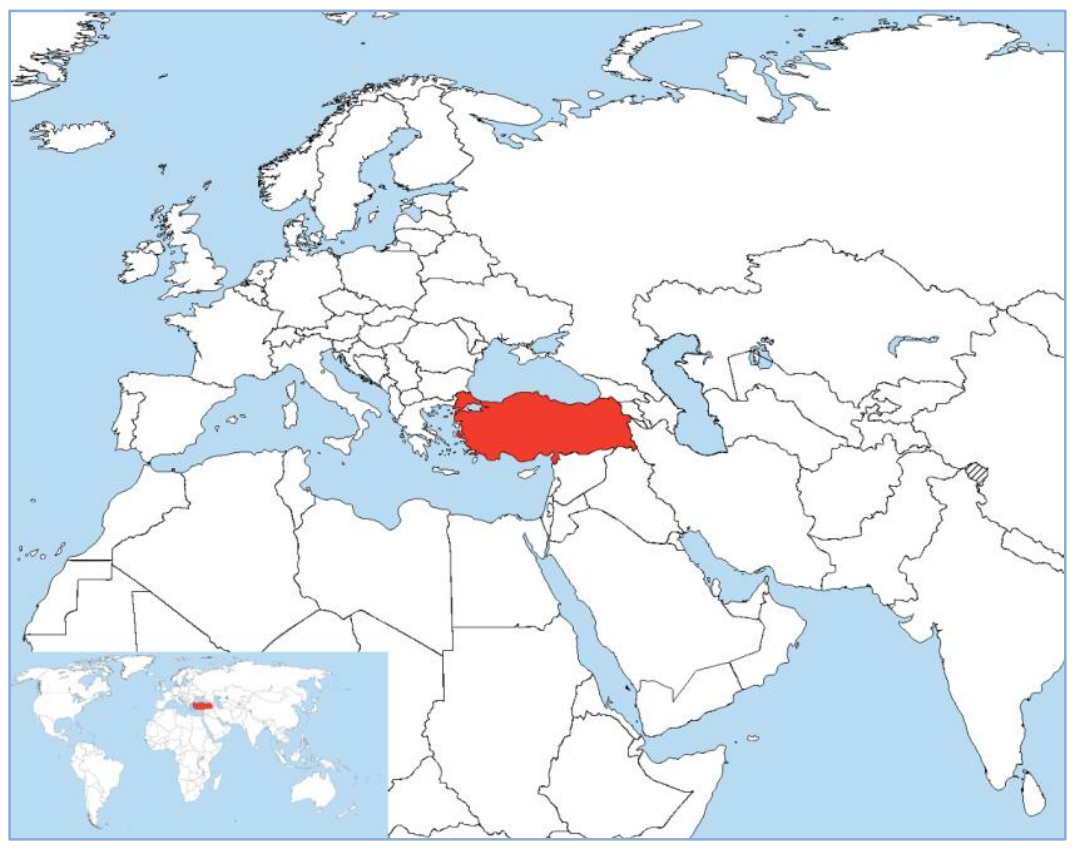

Figure 1. Location of Turkey in World map (https://medium.com/)

Next to German, French and English, Arabic is also offered as an elective language. Yet, most of the children in Turkey are taught English as a second language at school. However, the unusual relationship between English and Turkish due to their syntactic and morphological differences makes English exceptionally difficult for native speakers of Turkish to learn. In addition, a highly centralized education system in Turkey also likely influences the relatively low proficiency in English. Therefore, unless they are born in a bilingual family or a situation, in Turkey, children start learning a second language and its grammar in secondary school. The motivation or the attitude for learning a second language at that age and the amount of time that is invested in young peoples' learning of English are all considered factors for insufficient levels of English in Turkey (Maviş, 2010). However, in the meantime, the need for English to ensure job security and economic advancement makes the study of that language in Turkey a topic of interest (Thompson \& Erdil-Moody, 2016).

\subsection{A short description of the Turkish language and the Turkish context}

Turkish is the official language spoken mainly in Turkey and the surrounding regions and has about 70 million native speakers worldwide. Turkish is spoken in Turkish Republic of Northern Cyprus and by small groups of ethnic Turks in Iraq, Greece, Bulgaria, the Republic of Macedonia, Kosovo, Albania and some other regions of Eastern Europe. In Turkish, there are a large number of word borrowings, especially from Persian, Arabic and French. These loanwords usually fill a newly-formed linguistic need as a result of cultural contact or increasingly technological development, and are often phonologically or orthographically adapted into the language. 
Turkish belongs to the Altaic branch of the Ural-Altaic linguistic family. The canonical word order of Turkish is subject-object-verb. Yet, word order in Turkish is relatively flexible. A simple combination of predicate (verb), subject, and object may result in six possible orders - SOV, SVO, OSV, OVS, VOS, and VSO - in transitive sentences, all of which are grammatical in principle. The flexibility of word order has also been observed in narration. Aksu-Koç (1994) elicited narrative data from children and adult Turkish speakers using a picture book, The Frog Story (Mayer, 1969), and found that pro-drop sentences such as OV, VO, and V constitute about $50 \%$ of the narratives, while SOV and SV orders together were about 40\% (Ar1k, 2016).

Other distinctive characteristics of the Turkish language are vowel harmony and extensive agglutination; that is, Turkish depends on the morphological endings attached to content words. This means that our language tends to 'agglutinate' speech elements, which might be expressed in English by separate words such as prepositions or modal verbs. This process is widespread in Turkish. Affixes attached in sequence to the end of a word do the work of grammatical features. They build up nouns and supply verbs with tense and person. By this way, word structure (morphology) does more communicative work in Turkish than in languages like English, which depends on sentence structure (syntax) (Menn et al., 1990). The vowels of suffixes undergo vowel harmony. When a suffix is attached to a stem, the vowel in the suffix generally agrees in frontness or backness and in roundedness with the last vowel in the stem or of the preceding suffix.

In general, Turkish stems can be assigned to one of the two major categories nouns and verbs. Turkish verbs are very regular in forming their tenses. The verbs consist of three fundamental elements: verb root, tense particle(s) and personal endings. Verbs have six grammatical persons (three singular and three plural), various voices (active and passive, reflexive, reciprocal, and causative), and a large number of grammatical tenses. Meanings of negation, obligation, ability and/ or a condition (such as 'not, be able to, must', etc.), which are expressed as separate words in most European languages, are usually expressed with verbal suffixes in Turkish.

\subsection{Background of Turkish MAIN}

During the process of adapting the Multilingual Assessment Instrument of Narratives (LITMUS-MAIN, hereafter MAIN; Gagarina et al., 2012, 2019) to Turkish, some studies investigated narrative structure in Turkish-speaking monolingual and bilingual children (Maviş, Tunçer \& Akyıldız, 2011; Maviş et al., 2012). The results demonstrated that both monolingual and bilingual children could answer some comprehension questions correctly by about 4 years of age. The appropriate use of internal state terms appeared at age 6, regardless of mono- or bilingualism; however, age and internal state terms were not correlated. On the contrary, macrostructural components and comprehension improved with age.

Another study (Maviş et al., 2012) compared three Turkish-German speaking boys (ages 4-6 years) to three age-matched Turkish-speaking monolingual children living in Turkey. The two groups of children told a story based on a set of 6 pictures (Baby Birds or Baby Goats) and 
retold a story based on another set of 6 pictures (Cat or Dog). A non-parametric statistical analysis demonstrated no difference between the monolingual and bilingual groups regarding the macrostructure components (story structure, story complexity, use of internal state terms, and comprehension) on either 'the tell or retell' tasks.

Using MAIN (Gagarina et al., 2012), two studies examined the effects of age, gender and the narrative task on Turkish narrative skills of Turkish-German bilingual children (Maviş, Tunçer \& Gagarina, 2016). The first research objective was to assess the effects of age on the production and comprehension of macrostructure components in the first language - Turkish of bilingual children living in Germany. The second objective was to examine how gender impacts the production and comprehension of macrostructure. The last objective was to determine if different narrative tasks affect macrostructure components. In this study, 36 children; 21 girls and 15 boys aged from 2;11 to 7;11 (months; years) told stories in two conditions (tell-after model vs. tell-no model) and answered comprehension questions. All participants were Turkish-German simultaneous bilinguals who were born in Germany and had been living there since their birth, and were from Turkish families. They were attending monolingual German-speaking kindergartens/schools in Berlin, Singen and Konstanz. The studies showed significant age effects on story complexity and comprehension, but not story structure and internal state terms. There were no significant effects for gender. Comprehension was significantly better in the 'tell-after model' vs. 'tell-no model' condition (Study 1). For production (storytelling), a trend favouring 'retell' over 'tell' was found (Study 2).

\section{Adapting MAIN to Turkish}

Here, we describe the revised process of adapting MAIN to Turkish. The critical points in the translation process of MAIN to Turkish were related to: (a) the use of pronouns, (b) the conjunction 'and' in Turkish, and (c) typology of the language in general.

Turkish has no grammatical gender and the 3rd person pronoun 'o' (he/she/it) can be used for male, female and neutral referents. In the Baby Goats story, the personal pronoun 'him' in a sentence 'The fox let go of the baby goat and the bird chased him away', was substituted with the noun tilki 'fox' in the translation in order to avoid misunderstanding. Otherwise, 'him' might refer either to the fox or the baby goat for especially the children with DLD, who cannot follow the referents as typical children do. We observed the same problem in the sentence 'The cat let go of the baby bird and the dog chased him away'. To clarify whom the dog chases, we substitute the referent with the name itself as such Kedi yavru kuşu bırakmış ve köpek kediyi (onu) kovalamış.

Turkish is a pro-drop (pronoun-drop) language in which certain classes of pronouns may be omitted when they are pragmatically and/or grammatically apparent. Reflexive pronouns belong to this group. They are mostly used to emphasize the meaning and are therefore used with lesser frequency in Turkish. Hence, in some sentences the 'pronoun' was just omitted and the translation of 'The cat hurt himself' became as in (1). 
(1)

$\begin{array}{lll}\text { kedinin } & \text { canı } & \text { acımış } \\ \text { cat-GEN } & \text { self-3SG.POSS } & \text { hurt-PF } \\ \text { 'The cat hurt } & \text { himself' } & \end{array}$

Main clause predicates are necessarily marked for person in Turkish whereas subject pronouns are not always necessary. Accordingly, if the pronoun has a clear noun antecedent, we do not have to emphasize the doer of the action to avoid redundancy as seen in (2).

$$
\begin{array}{clc}
\varnothing \text { yavru } & \text { kuşlardan birini } & \text { yakalamış } \\
\text { baby } & \text { bird-PL-GEN one-3SG.ACC } & \text { grab-PF } \varnothing
\end{array}
$$

'He grabbed one of the baby birds'

In regard to such flexibility, pronouns were also omitted in the translation of 'One day there was a mother goat who saw that baby goat had fallen into the water and that it was scared' (Bir gün anne keçi yavrusunun suya düştüğ̈nü ve [onun] korktuğunu görmüş) and 'The mother bird came back with a big worm for her children, but she did not see the cat' (Anne kuş yavrulart için büyük bir solucan getirmiş fakat [o] kediyi görmemişti).

In Turkish, the conjunction ve 'and' is used to link two sentences in the same syntactic level, and both the sentences before and after the conjunction express either positive or negative meaning. Yet, children tend to process connected sentences easily if the doers of the both sentences are the same. In the story Baby Birds, when we examined the sentence 'The dog was very glad that he could save the birds, and the cat was still hungry', we decided that the connection ve 'and' does not imply the opposing idea between the sentences in Turkish so we changed ve to ama 'but'. Consequently, Turkish translation appeared as Köpek kuşları kurtardı ̆̆ için çok memnun olmuş ama kedi hala açmış. The same is available for the parallel structure in Baby Goats.

As is well known, Turkish is an agglutinating language with rich suffixation; however, there are no articles such as the/a/an in this language. As a result, the number of words in the four stories was lower than those in the English version.

In the stories Cat and the Dog, new structures such as 'the ball was saved' or 'the balloon was saved' were added to the correct responses of the revised version of the English MAIN. The usage of such constructions is common in English; yet, in their responses, Turkish children did not prefer the ball or the balloon topicalized with a passive morphology. Children preferred an active structure as 'the boy saved the ball/the balloon,' shifting their focus more toward the doer of the action.

The last revision is related to the sentences in Cat and Dog stories 'the cat noticed the boy's bucket and thought: 'I want to grab a fish.' and 'the dog noticed the boy's bag and thought: 'I want to grab a sausage.' In Turkish, the children ignored that intentional thinking simply saying, 'the dog/the cat wants to grab a fish/a sausage.' Thus, to make the children use the internal term 'thinking', we changed the present tense to a subjunctive/optative mood like 
alayım/alsam, as in kedi çocuğun kovasını gördü ve kovadan bir balık alsam/alayım diye düşündü 'the cat saw the bucket and the cat thought/desired he would grab a fish from the bucket.' Optative mood seems to fit more in Turkish context.

\section{The use of the Turkish MAIN (MAIN-TR)}

During 2011-2012, 17 languages (Afrikaans, Albanian, Croatian, Cypriot Greek, Dutch, English, Finnish, French, German, Greek, Hebrew, Italian, Lithuanian, Russian, Swedish, Turkish) were represented in the MAIN-LITMUS project (within COST Action IS0804); where two members participated from Turkey: İlknur Maviş and A. Müge Tunçer. We attended most of the WG meetings and each time, we presented a pilot study with monolinguals (15 children) and bilinguals; children with Turkish-German (21 children) and Turkish-Kurdish (7 children). In the revised 2020 version of MAIN-TR, which is based on the revised MAIN (Gagarina et al., 2019), the stories have been checked for translation into Turkish from English, considering the macrostructure elements in the context of story structure, structural complexity and internal state terms. The stories have been controlled for linguistic complexity, parallelism in macrostructure and microstructure and both for cultural and linguistic appropriateness.

Nowadays, Semra Selvi Balo, a research assistant writing her PhD thesis at Anadolu University, carries out a validity and reliability study of MAIN-TR. The participants of the study are typically developing monolingual children between 36 to 72 months and a group of age matched children with Developmental Language Disorder (DLD). Recently, she did a pilot testing with a small group of participants; 13 typically developing children between 45-75 months ( $M=62$ months) and 7 children with developmental language disorder between 49-72 months ( $M=57$ months), attending DILKOM, a speech and language therapy centre in Eskişehir, Turkey. The children were first assessed for language development by Turkish version of Test of Early Language Development-3 (TEDİ; Topbaş \& Güven, 2011), then were administered model story-tell and retell-tell in alternative modes using MAIN-TR, which lasted almost about 20 minutes per child. Story structure components, structural complexity, internal state terms and the comprehension questions were scored.

The findings of the pilot study showed that MAIN-TR is a useful task to discriminate the child with developmental language disorder from the typically developing child in macrostructure analysis. Yet, it was surprising to observe that typically developing children do not start narrating with an opening phrase such as 'once upon a time, one day, or in the forest, etc...', regardless of the narration mode. The pictures of the stories seemed cultural and age appropriate. Yet, most of the children have misnamed the 'fox' for a wolf and the 'bird' for a crow; which we relate the naming problems either to their insufficient familiarity to the animal world or their frequent exposure to the stories more with wolves rather than foxes. When the children saw the mother goat saved the baby goat and was glad that the baby was not drown, they said the mother goat missed her baby very much. Some children told the baby goat is crying but instead the verb 'cry', they said the baby goat is bleating (mee diyor). Considering 
the comments, in 2020 version of MAIN-TR, 'missing and getting sad' are added into the list of internal emotional terms.

The typically-developing children were quite competent in answering the questions tapping theory of mind (ToM) compared to the children with DLD. For example, when the children were asked 'Will the boy be friends with the dog? Why?', typically-developing children gave reasonable explanations: 'No because the dog ate all the sausages,' 'No because the boy would take the sausages to home and give his mum, but the dog ate all,' 'No because the boy had already paid for the sausages, but the dog ate them all,' etc. On the other hand, children with DLD often misunderstood the question saying 'Yes, they would be friends', without any reasons. The aim of the ToM questions is to see if the child can infer meaning about the story as a whole. It is clear that Turkish-speaking monolingual children with DLD show lower performances inferring meaning or taking the perspective of others.

So far, the adaptation of MAIN to Turkish has been finalized by some pilot studies, including small number of participants. As we mentioned, the reliability and validity study of MAIN-TR is ongoing with age groups of 3 to 6 regarding macrostructure analysis. The microstructure analysis of MAIN-TR has been studied for a small group of children but will be studied from a broad perspective to elicit syntactic development of the Turkish-speaking children, both typical and/or disordered. When we reach to the age based normative values, we plan to carry out projects with bilingual/multilingual children, children with autism and children with special needs.

These studies reflect how narratives will be discriminative to identify disordered children from their typically developing peers. As one of the traditional modes of discourse, narration should be used in adult language disorders as well. It is certain that the participant groups of aphasia, primary progressive aphasia and Alzheimer's disease will benefit from the narratives both in assessment and therapy.

\section{$4 \quad$ References}

Aksu-Koç, Ayhan (1994) Development of linguistic forms: Turkish. In R. A. Berman \& D. I. Slobin (Eds.) Relating events in narrative: A crosslinguistic developmental study (pp. 329-385). Hillsdale, New Jersey: Lawrence Erlbaum.

Arık, E. (2016). An experimental approach to basic word order in Turkish intransitives. Psychology of Language and Communication, 20(1), 73-91.

Gagarina N., Klop D., Kunnari S., Tantele K., Välimaa T., Balčiūnienė I., Bohacker U., \& Walters J. (2012). MAIN: Multilingual Assessment Instrument for Narratives. ZAS Papers in Linguistics, 56.

Gagarina, N., Klop, D., Kunnari, S., Tantele, K., Välimaa, T., Bohnacker, U. \& Walters, J. (2019). MAIN: Multilingual Assessment Instrument for Narratives - Revised. ZAS Papers in Linguistics, 63.

Grimes BF. (1992) Ethnologue: Languages of the World. Dallas, Texas: Summer Institute of Linguistics Mayer, M. (1969). Frog, where are you? New York: Dial Press. Chicago. 
Maviş, İ. (2010). Characteristics of Aphasia in Turkish. In: S. Topbaş \& M. Yavaş, Communication disorders in Turkish. Multilingual Matters.

Maviş, İ., Tunçer, A. M., \& Akyıldız, D. (2011). Administering the Baby Birds to bilingual children speaking Turkish-Kurdish (TR/KR) and monolingual children speaking Turkish. Poster session presented at COST ACTION ISO804, Fifth MC \& WGs Meeting, Malta.

Maviş, İ., Gagarina N., Tunçer A. M., Ünal Ö., Yeleğen D., Akyıldız D. \& Akpınar, D. (2012). Administering the telling (Baby Birds/Baby Goats) \& re-telling (Cat/Dog) stories to Turkish-German bilingual children living in Berlin. Paper presented at COST ACTION IS0804, Sixth MC \& WGs Meeting, Berlin.

Maviş, İ., Tunçer, A.M. \& Gagarina, N. (2016). Macrostructure components in narrations of Turkish-German bilingual children. Applied Psycholinguistics, 37(1), 69-89.

Menn, L. \& Obler, L.K. (1990). Agrammatic Aphasia: Cross-Language Narrative Sourcebook. Amsterdam/Philadelphia: John Benjamins.

Schaufeli, A. (1991). Turkish in an immigrant setting: A comparative study of the first language of monolingual and bilingual Turkish children. Unpublished PhD dissertation, Amsterdam University, Amsterdam, the Netherlands.

Thompson A. S \& Erdil-Moody Z (2016) Operationalizing multilingualism: language learning motivation in Turkey, International Journal of Bilingual Education and Bilingualism, 19(3), 314-331.

Topbaş, S. \& Güven, S. (2011). Türkçe Erken Dil Gelişim Testi-TEDİL-3. Ankara: Detay Yayınc1lık.

Topbaş, S. (2007). Turkish Speech Acquisition. In: S. McLeod (Ed.), The international guide to speech acquisition (pp. 2-7). Clifton Park, NY: Thomson Delmar Learning.

Topbaş, S. (2006). A Turkish perspective on communicative disorders. Logopedics, Phoniatrics and Vocology, $31(2), 76-88$

Turkish Ministry of Foreign Affairs. Available at http://www.disisleri.gov.tr. Accessed on 24 October, 2003.

Yagmur, K. (1997). First Language Attrition among Turkish Speakers in Sydney. Tilburg, the Netherlands: Tilburg University Press.

Worldometer (2020). Turkey population (2020) (retrieved from https://www.worldometers.info/worldpopulation/turkey-population/). 